\title{
Pengaruh penambahan Ion Logam Natrium, Kalium, Magnesium, Kalsium pada biokonversi tepung jagung (Zea Mays L.) oleh Ragi Endomycopsis Fibuligera menjadi Senyawa Prebiotik
}

\author{
Astuti Amin*, Asnita, Nurul Ilma Bunyamin, Hidayah \\ Sekolah Tinggi Ilmu Farmasi Makassar, Makassar, 90241, Indonesia
}

INFO ARTIKEL

Diterima 23 Januari 2020

Disetujui 28 April 2020

Key word:

Prebiotics

Endomycopsis fibuligera

metal ions

broiler livestock

\section{Kata kunci:}

Prebiotik

Endomycopsis fibuligera

ion logam

Ternak ayam pedaging

\author{
A B STR A C T
}

In this study made prebiotic from bioconversion of corn flour (Zea mays L.) by yeast Endomycopsis fibuligera as an alternative substitute for antibiotics. In this study, the addition of $\mathrm{Na}^{+}, \mathrm{K}^{+}, \mathrm{Ca}^{2+}$, and $\mathrm{Mg}^{2+}$ ions aimed to determine the optimum type and concentration of metal in prebiotic and testing the effect of prebiotic compounds produced on broiler weight gain. The analysis carried out included: reducing sugars, $\alpha$-amylase and glucoamylase enzyme activity, protein content and cell biomass. To determine the existence of a significant effect, the analysis was carried out on broiler body weight given prebiotic compounds which were added to optimum metal ions and which were given prebiotic compounds without the addition of metal ions. The results showed that the addition of optimum metal ions was obtained on $\mathrm{Ca}^{2+}$ ions with a concentration of $0.25 \%$, where the reducing sugar content of 0.600 $\mathrm{mg} / \mathrm{mL}$, the activity of the enzyme $\alpha$-amylase and glucoamylase 0.519 and 0.287 units / $\mathrm{mL}$, protein content $2.724 \mathrm{mg} / \mathrm{mL}$, cell biomass $10.8933 \mathrm{mg} / \mathrm{mL}$, from observations and statistical tests carried out by giving prebotic compounds by adding metal ions and giving prebiotic compounds without adding metal ions influence broiler weight gain with an average weight difference of 261 grams or $15 \%$ on day 30 .

\section{A B STRAK}

Pada penelitian ini dibuat prebiotik dari biokonversi tepung jagung oleh ragi Endomycopsis fibuligera sebagai alternatif pengganti antibiotik. Pada penelitian ini dilakukan penambahan ion logam $\mathrm{Na}^{+}, \mathrm{K}^{+}, \mathrm{Ca}^{2+}$ dan $\mathrm{Mg}^{2+}$ yang bertujuan untuk menentukan jenis dan konsentrasi ion logam yang optimum pada prebiotik dan menguji pengaruh senyawa prebiotik yang dihasilkan terhadap pertambahan berat badan ayam pedaging. Analisis yang dilakukan meliputi : gula pereduksi, aktivitas enzim $\alpha$-amilase, glukoamilase, kadar protein dan biomassa sel. Untuk mengetahui adanya pengaruh yang signifikan, maka analisis dilakukan terhadap berat badan ayam pedaging yang diberi senyawa prebiotik yang ditambahkan ion logam yang optimum dan yang diberi senyawa prebiotik tanpa penambahan ion logam. Hasil penelitian menunjukkan bahwa penamabahan ion logam optimum diperoleh pada ion $\mathrm{Ca}^{2+}$ dengan konsentrasi $0,25 \%$, dimana kadar gula pereduksi $0,600 \mathrm{mg} / \mathrm{mL}$, aktifitas enzim $\alpha$-amilase dan glukoamilase masing-masing 0,519 dan 0,287 unit/mL, kadar protein 2,724 mg/mL, biomassa sel 10,8933 mg/mL, dari pengamatan dan uji statistik yang dilakukan dengan pemberian senyawa prebiotik dengan penambahan ion logam dan pemberian senyawa prebiotik tanpa penambahan ion logam berpengaruh terhadap pertambahan berat badan ayam pedaging dengan selisih berat rata-rata 261 gram atau $15 \%$ pada hari ke 30. 


\section{Pendahuluan}

Penggunaan antibiotik atau antimikrobial sebagai bahan aditif untuk ternak telah berlangsung lebih dari 40 tahun. Antibiotik tersebut digunakan sebagai growth promotor dalam jumlah yang relatif kecil namun dapat meningkatkan efisiensi pakan (feed efficiency) dan reproduksi ternak sehingga dengan penggunaan bahan aditif tersebut peternak dapat memperoleh keuntungan lebih. Namun, akhir-akhir ini penggunaan antibiotik mengalami penurunan dan bahkan di beberapa negara telah melarang penggunaan antibiotik untuk ternak. Hal ini disebabkan karena dua faktor utama. Hadirnya residu antibiotik yang akan menjadi racun bagi konsumen, di samping itu antibiotik dapat menciptakan mikroorganisme yang resisten dalam tubuh manusia dan ternak terutama bakteribakteri patogen seperti Salmonella, E. coli dan Clostidium perfrinens.

Sebagai pengganti antibiotik nutritionist merekomendasikan peternak menggunakan senyawa prebiotik sebagai pengganti antibiotik. Senyawa prebiotik merupakan bahan yang tidak dapat dicerna oleh ternak berperut tunggal (monogastric) seperti ayam dan babi. Senyawa prebiotik tersebut dapat menjadi pemicu untuk meningkatkan bakteri yang menguntungkan bagi ternak seperti Lactobacillus dan Bifidobacteria. Komposisi bakteria pada saluran pencernaan didominasi oleh bakteri Bacteriodes sebesar $72 \%$ sementara pemberian senyawa prebiotik seperti oligofruktosa atau inulin meningkatkan komposisi Bifidobacteria sampai 81\% [1].

Pemberian senyawa prebiotik dapat meningkatkan respon imun, mengurangi penyakit infeksi dan inflamasi pada ternak [2]. Senyawa prebiotik juga dapat meningkatkan pertumbuhan dan daya tahan terhadap penyakit pada anak [3]. Salah satu usaha yang dapat dilakukan untuk meningkatkan produktivitas ayam pedaging adalah memberikan senyawa prebiotik hasil fermentasi dari substrat tepung jagung. Tepung jagung mengandung amilosa $27 \%$ dan amilopektin $73 \%$. Tepung jagung difermentasi untuk memperoleh senyawa prebiotik dengan menggunakan ragi Endomycopsis fibuligera. Selain itu, produk hasil fermentasi tepung jagung mempunyai kandungan protein yang cukup tinggi [4].

Ragi Endomycopsis fibuligera menghasilkan enzim amilase yang mempunyai kemampuan untuk memecah molekul-molekul pati. Amilase merupakan enzim yang bergantung pada ion logam terutama ion divalent seperti $\mathrm{Ca}^{2+}, \mathrm{Mg}^{2+}, \mathrm{Mn}^{2+}, \mathrm{Zn}^{2+}, \mathrm{Fe}^{2+}$. Pada penelitian sebelumnya diperoleh kondisi optimum pada penambahan 10\% inokulum, waktu fermentasi 96 jam dan konsentrasi tepung sagu $1 \%$ pada media fermentasi. Hasil yang diperoleh diberikan pada ayam potong tanpa pemberian antibiotik dan vitamin, namun hasilnya belum maksimal dimana berat badan ayam potong yang diberi senyawa prebiotik tidak memberikan pengaruh yang signifikan terhadap berat badan ayam potong dibandingkan dengan perlakuan kontrol (antibiotik) [4].

\section{Bahan dan Metode}

Bahan yang digunakan dalam penelitian ini antara lain: ragi Endomycopsis fibuligera, natrium sitrat monohidrat $\left(\mathrm{Na}_{3} \mathrm{C}_{6} \mathrm{H}_{5} . \mathrm{H}_{2} \mathrm{O}\right)$, natrium dihidrogen phosfat $\left(\mathrm{NaH}_{2} \mathrm{PO}_{4}\right)$, garam rochelle $\left(\mathrm{C}_{4} \mathrm{H}_{4} \mathrm{KNaO}_{6} .4 \mathrm{H}_{2} \mathrm{O}\right)$, bovine serum albumin (BSA), dinitro salisilic acid (DNSA), glukosa anhidrat $\left(\mathrm{C}_{6} \mathrm{H}_{12} \mathrm{O}_{6}\right)$, tambaga sulfat $\left(\mathrm{CuSO} .5 \mathrm{H}_{2} \mathrm{O}\right)$, natrium karbonat $\left(\mathrm{Na}_{2} \mathrm{CO}_{3}\right)$, natrium hidroksida $(\mathrm{NaOH})$, larutan buffer $\mathrm{pH}$ 5 dan $\mathrm{pH} 4,8$, fenolfolin-ciocalteus $1 \mathrm{~N}$, etanol $\left(\mathrm{CH}_{2} \mathrm{H}_{5} \mathrm{OH}\right)$, magnesium klorida heksahidrat $\left(\mathrm{MgCl}_{2} .6 \mathrm{H}_{2} \mathrm{O}\right)$, kalsium klorida dihidrat $\left(\mathrm{CaCl}_{2} 2 \mathrm{H}_{2} \mathrm{O}\right)$, tepung jagung, ektrak tauge, aluminium foil, ekstrak ragi, akuades, agar bakto, kapas, tali dan kain kasa, kertas $\mathrm{pH}$, natrium klorida $(\mathrm{NaCl})$, kalium klorida $(\mathrm{KCl})$, spiritus, aquabidest.

\section{Pembuatan Media Inokulum}

Ekstrak ragi dan tepung jagung ditimbang masing-masing sebanyak 1 gram lalu dilarutkan dengan akuades sebanyak 100 $\mathrm{mL}$ di dalam erlemeyer $250 \mathrm{~mL}$ sambil diaduk dan dipanaskan hingga larut. Setelah itu media ditutup rapat dengan kapas dan perban, kemudian dibungkus dengan aliminium foil. Dan media inokulum disterilkan dalam autoklaf selama kurang lebih 15 menit pada suhu $121^{\circ} \mathrm{C}$. 
Pembuatan Media Fermentasi (Media Produksi)

Ekstrak ragi dan tepung jagung masingmasing di timbang sebanyak 1 gram dan NaH2PO4 0,1 gram, ditambahkan ion logam $\left(\mathrm{Na}^{+}, \mathrm{K}^{+}, \mathrm{Mg}^{+}\right.$dan $\left.\mathrm{Ca}^{2+}\right)$ kedalam lima buah erlenmeyer $250 \mathrm{~mL}$ kemudian ditambahkan akuades sebanyak $100 \mathrm{~mL}$. Setelah itu, dipanaskan sambil diaduk hingga larut, lalu ditutup rapat dan disterilkan didalam autoklaf selama kurang lebih 15 menit pada suhu $121^{\circ} \mathrm{C}$, kemudian didinginkan pada temperature ruang.

\section{Peremajaan Ragi}

Ruang tempat pemindah mikroba disterilkan dengan menyemprotkan etanol sekitarnya. Kawat ose dipanaskan pada pembakar spiritus hingga berpijar, kemudian didinginkan sejenak, mikroba dari kultur induk diambil. Kawat ose digoreskan secara zig-zag pada permukaan media agar miring di atas pembakar spirtus lalu ditutup kembali dengan kapas. Media agar miring yang telah digores dimasukkan ke dalam inkubator selama $2 \times 24$ jam pada suhu kamar.

\section{Penyiapan Inokulum}

Kawat ose dipanaskan di atas permukaan api hingga berpijar, kemudian didinginkan sejenak. Mikroba dari kultur induk diambil, lalu dimasukkan ke dalam media inokulum yang telah disterilkan. Biakan dimasukkan kedalam shaker inkubator pada suhu kamar selama 48 jam.

\section{Fermentasi Media Produksi}

Sebanyak $10 \mathrm{~mL}$ media inokulum aktif yang telah diproduksi dipindahkan ke dalam media produksi sebanyak $10 \%$ dari medai inokulum pada masingmasing erlenmeyer. Pemindahan ini di lakukan di dalam alat pemindah mikroba dan di atas api spirtus. Media produksi yang telah mengandung mikroba dikocok selama 96 jam atau diinkubasi pada suhu kamar, 150 rpm selama 1-4 hari kemudian dilakukan sampling untuk mengukur, biomassa sel, kadar protein, gula preduksi, aktivitas enzim alfa-amilase dan aktivitas glukoamilase.
Uji Pengaruh Senyawa Prebiotik yang Dihasilkan Terhadap Pertambahan Berat Badan Ayam Pedaging Produk yang dihasilkan (senyawa prebiotik) diberikan pada ternak ayam caranya: sampel diencerkan dengan air, dengan perbandingan sampel dengan air 1:2 dan diberikan pada ternak ayam pedaging dari umur 1 hari hingga panen yaitu umur 21 hari dan diberikan 3 hari berturut-turut dan diselingi dengan pemberian air putih 2 hari berturut-turut.

Pada penelitian ini digunakan 50 ekor ayam pedaging untuk pemberian senyawa prebiotik dengan penambahan logam dan 50 ekor untuk pemberian senyawa prebiotik tanpa penambahan ion logam, Penimbangan dilakukan setiap hari, sebagai kontrol yaitu senyawa prebiotik tanpa penambahan ion logam.

Analisis Senyawa Prebiotik dengan Penambahan masing-masing Ion Logam

1. Penentuan Gula Pereduksi dengan Metode Miller (DNSA)

Larutan enzim ekstrak kasar dipipet sebanyak $1 \mathrm{~mL}$ ke dalam tabung reaksi, lalu ditambahkan $3 \mathrm{~mL}$ reagen dinitro asam salisilat (DNSA) dan dilakukan pengenceran jika sampel terlalu pekat. Kemudian tabung reaksi dipanaskan selama 5 menit pada suhu 100OC, kemudian langsung dimasukkan ke dalam wadah yang berisi es. Serapan warna dari produk diukur pada panjang gelombang optimum dengan menggunakan spektrofotometer UV/VIS.

\section{Penentuan Kadar Protein dengan Metode Lowry}

Kadar protein supernatan ditentukan dengan metode Lowry dengan menggunakan standar BSA (Bovine Serum Albumin). BSA sebanyak 0,01 gram ditimbang, lalu dilarutkan dengan air suling sebanyak $20 \mathrm{~mL}$. Pereaksi untuk penentuan kadar terdiri dari larutan $\mathrm{B}$; 0,5gram $\mathrm{CuSO} 4.5 \mathrm{H} 2 \mathrm{O}$ dan 1 gram Na3C6H5O7.H2O dilarutkan dalam air suling sampai volume akhir menjadi $100 \mathrm{~mL}$. larutan A; 2 gram $\mathrm{Na} 2 \mathrm{CO} 3$ dan 0,4 gram $\mathrm{NaOH}$ dilarutkan dalam air suling sampai volume akhir menjadi 100 mL. Larutan C dibuat dengan mencampurkan $1 \mathrm{~mL}$ larutan $\mathrm{B}$ dan $50 \mathrm{~mL}$ larutan A. larutan D ; pereaksi Fenol folin- 
ciocalteus $1 \mathrm{~N}$, prosedur percobaan adalah sebagai berikut: sebanyak $0,5 \mathrm{~mL}$ larutan enzim ekstrak kasar ditambahkan 2,5 mL pereaksi C kemudian dikocok dan disimpan pada suhu kamar selama 10 menit. Kedalam campuran tersebut ditambahkan $0,25 \mathrm{~mL}$ pereaksi $\mathrm{D}$, dikocok dan dibiarkan selama 30 menit. Warna biru hasil reaksi diukur serapannya pada panjang gelombang $(\lambda) 720 \mathrm{~nm}$.

\section{Penentuan Biomassa Sel (Metode Penimbangan)}

Larutan enzim ekstrak kasar dipipet masing-masing sebanyak $5 \mathrm{~mL}$, lalu disaring dengan kertas saring Whatman dan dicuci dengan air suling hingga diperoleh $\mathrm{pH}$ netral ( $\mathrm{pH}$ 7). Substrat kemudian dikeringkan hingga diperoleh berat konstan pada suhu $800^{\circ} \mathrm{C}$. Konsentrasi biomassa dinyatakan dalam berat per volume.

\section{Penentuan Aktivitas enzim $\alpha$-amilase}

Uji aktivitas $\alpha$-amilase menggunakan metode yang digunakan oleh Kartini [4]. Adapun prosedur untuk Enzim ekstrak kasar adalah sebagai berikut : 0,250 $\mathrm{mL}$ Larutan enzim ekstrak kasar dimasukkan ke dalam tabung reaksi lalu ditambahkan $1,25 \mathrm{~mL}$ pati larut (1\%), kemudian ditambahkan 0,25 mL larutan buffer asetat $(\mathrm{pH} 5)$ diinkubasi selama 10 menit pada suhu $500^{\circ} \mathrm{C}$ setelah diinkubasi ditambahkan $1 \mathrm{~mL}$ DNSA, kemudian dipanaskan selama 10 menit, didiamakan 5 menit dengan menggunakan air suling. Serapan warna dari kontrol dan sampel diukur pada panjang gelombang $575 \mathrm{~nm}$ dengan menggunakan spektrofotometer UV/VIS.

5. Penentuan Aktivitas Enzim Glukoamilase

Uji aktivitas enzim glukoamilase dilakukan berdasarkan metode yang digunakan oleh Paulchami, C., (2008). Sebanyak 0,1 $\mathrm{mL}$ Larutan enzim ekstrak kasar ditambahkan $1 \mathrm{~mL}$ larutan pati $1 \%, 1 \mathrm{~mL}$ larutan buffer $\mathrm{pH}$ 4,8 kemudian diinkubasi pada suhu $50 \mathrm{oC}$ selama 20 menit. DNSA sebanyak $3 \mathrm{~mL}$ di tambahkan lalu dipanaskan selama 10 menit kemudian didinginkan dalam air selama 15 menit dan serapannya diukur pada panjang gelombang $575 \mathrm{~nm}$. Aktivitas enzim glukoamilase dihitung berdasarkan data kadar glukosa relatif sebagai mg glukosa yang dihasilkan per mil filtrat enzim dengan menggunakan rumus :

$$
A E=\frac{M G X 1000}{B M g X M I}
$$

Dimana

$$
\begin{aligned}
& \text { AE : Aktivitas enzim (unit/mL) } \\
& \text { MG : Berat glukosa } \\
& \text { BMg : Berat molekul glukosa } \\
& \text { MI : Masa inkubasi. }
\end{aligned}
$$

6. Analisis Pengaruh Pertambahan Berat Badan Ayam Potong

Analisis yang digunakan pada penelitian ini adalah analisi statistik dengan menggunakan metode pengukuran berulang (Repeated Measure), data di input sebagai data longitudinal, dipisahkan sebagai sampel tunggal (berat badan) dan multi sampel (data perlakuan). Kemudian data diolah dengan program SPSS.

\section{Hasil dan Pembahasan}

Prebiotik merupakan nutrisi yang sesuai bagi bakteri baik, tapi tidak cocok bagi bakteri jahat, sehingga bisa meningkatkan bakteri baik dalam usus. Prebiotik yang paling potensial adalah karbohidrat (seperti oligosakarisa).

Penambahan ion logam $\mathrm{Na}^{+}, \mathrm{K}^{+}, \mathrm{Mg}^{+}$dan $\mathrm{Ca}^{2+}$ pada media fermentasi dan sebagai kontrol negatif yaitu fermentasi tanpa penambahan ion logam. Produk hasil fermentasi (senyawa prebiotik) dianalisis meliputi kadar gula pereduksi, aktivitas enzim $\alpha$-amilase, glukoamilase, kadar protein dan biomassa sel. Kondisi optimal diaplikasikan ke ternak ayam pedaging dan sebagai pembanding adalah pemberian tanpa penambahan ion logam. Sampel ayam pedaging masing-masing berjumlah 30 ekor dan dilakukan penimbangan setiap hari mulai hari 0 sampai 30 hari. Dilakukan uji statistik untuk mengetahui apakah ada pengaruh signifikan antara berat badan ayam pedaging yang diberi prebiotik dengan penambahan ion logam yang optimum dengan berat badan ayam pedaging yang diberi prebiotik tanpa penambahan ion logam pada media fermentasi. Adapun hasil yang diperoleh adalah sebagai berikut: 
Pengaruh Penambahan Ion Logam $\mathrm{Na}+, \mathrm{K}+, \mathrm{Mg}+$ dan Ca2+ Terhadap Kadar Senyawa Prebiotik

\section{Kadar Gula Pereduksi Senyawa Prebiotik}

Adapun kadar gula pereduksi yang diperoleh dengan penambahan ion logam logam $\mathrm{Na}^{+}, \mathrm{K}^{+}, \mathrm{Mg}^{+}$dan $\mathrm{Ca}^{2+}$ dan kadar gula pereduksi tanpa penambahan ion logam selama proses fermentasi sebagai berikut.

Tabel 1. Kadar Gula Pereduksi

\begin{tabular}{|c|c|c|c|c|}
\hline \multirow{2}{*}{$\begin{array}{c}\text { Konsentrasi } \\
(\%)\end{array}$} & \multicolumn{4}{|c|}{ Kadar qula pereduksi setelah penambahan $(\mathrm{mg} / \mathrm{mL})$} \\
\cline { 2 - 5 } & \multicolumn{4}{|c|}{ Kontrol $=0,375$} \\
\cline { 2 - 5 } & $\mathrm{Na}^{*}$ & $\mathrm{~K}$ & $\mathrm{Ca}^{+*}$ & $\mathrm{Mg}^{{ }^{*}}$ \\
\hline 0.10 & 0.410 & 0.461 & 0.502 & 0.423 \\
\hline 0.15 & 0.431 & 0.503 & 0.522 & 0.472 \\
\hline 0.20 & 0.485 & 0.454 & 0.542 & 0.518 \\
\hline 0.25 & 0.467 & 0.446 & 0.600 & 0.556 \\
\hline 0.30 & 0.436 & 0.444 & 0.519 & 0.501 \\
\hline
\end{tabular}

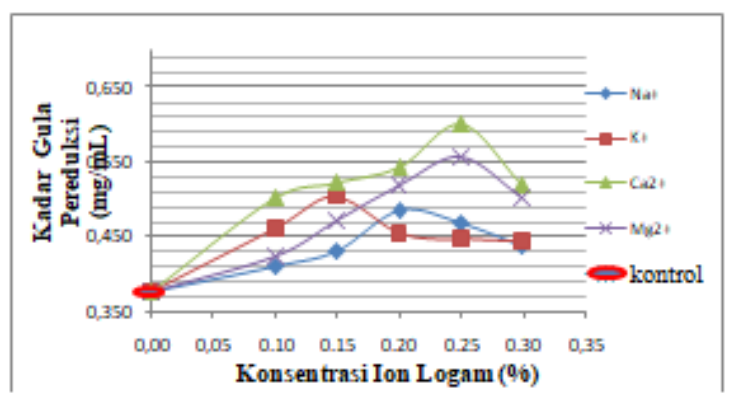

Grafik 1. Kadar Gula Pereduksi

Dari tabel 1 dan grafik 1 menunjukka bahwa penambahan ion logam $\mathrm{Na}^{+}, \mathrm{K}^{+}, \mathrm{Mg}^{2+}$ dan $\mathrm{Ca}^{2+}$ pada konsentrasi dan perbandingan tertentu berpengaruh terhadap kadal gula pereduksi senyawa prebiotik yang dibandingkan dengan kadar gula pereduksi senyawa prebiotik tanpa penambahan ion logam (kontrol).

Dari keempat jenis ion logam yang ditambahkan pada media substrat pati jagung, ion logam divalen $\left(\mathrm{Mg}^{2+}\right.$ dan $\left.\mathrm{Ca}^{2+}\right)$ lebih cocok sebagai kofaktor enzim $\alpha$-amilase dan glukoamilase daripada ion monovalen $\left(\mathrm{Na}^{+}\right.$dan $\mathrm{K}^{+}$). Hal ini disebabkan kedua ion $\mathrm{Mg}^{2+}$ dan $\mathrm{Ca}^{2+}$ tersebut dapat mengganti ion logam yang kurang efektif pada sisi aktif enzim $\alpha$-amilase dan glukoamilase sehingga aktivitas kedua enzim lebih sar dan kedua enzim tersebut lebih stabil yang menyebabkan ikatan amilosa dan amilopektin pati jagung semakin banyak yang terputus dan ini ditandai dengan kadar gula pereduksi yang paling optimum dibandingkan dengan penambahan ion $\mathrm{Na}^{+}$dan $\mathrm{K}^{+}$. Ion logam divalen yang paling sesuai adalah ion $\mathrm{Ca}^{2+}$ dengan konsentrasi $25 \%$.

\section{Aktivitas Enzim $\alpha$-Amilase dan Glukoamilase}

Tabel 2. Aktivitas Enzim $\alpha$-Amilase

\begin{tabular}{|c|c|c|c|c|}
\hline \multirow{2}{*}{$\begin{array}{c}\text { Konsentrasi } \\
(\%)\end{array}$} & \multicolumn{4}{|c|}{$\begin{array}{c}\text { Aktivitas enzim alfa-amilas setelah penambahan } \\
\text { (Unit/mL) }\end{array}$} \\
\cline { 2 - 5 } & \multicolumn{3}{|c|}{ Kontrol=0,056 } \\
\cline { 2 - 5 } & $\mathrm{Na}^{*}$ & $\mathrm{~K}$ & $\mathrm{Ca}^{{ }^{*}}$ & $\mathrm{Mg}^{{ }^{*}}$ \\
\hline 0.10 & 0.192 & 0.140 & 0.258 & 0.256 \\
\hline 0.15 & 0.214 & 0.293 & 0.383 & 0.310 \\
\hline 0.20 & 0.296 & 0.264 & 0.488 & 0.382 \\
\hline 0.25 & 0.225 & 0.218 & 0.519 & 0.443 \\
\hline 0.30 & 0.190 & 0.162 & 0.361 & 0.232 \\
\hline
\end{tabular}

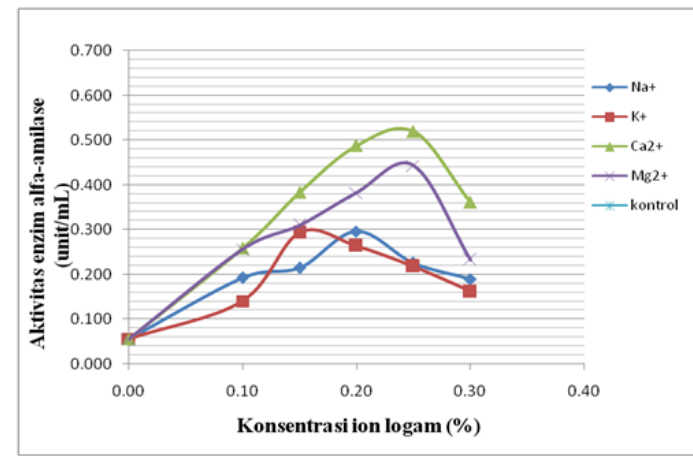

Gambar 2. Aktivitas Enzim $\alpha$-Amilase

Dari tabel 2 dan 3 menunjukkan dengan penambahan ion logam $\left(\mathrm{Na}^{+}, \mathrm{K}^{+}, \mathrm{Mg}^{+}\right.$dan $\left.\mathrm{Ca}^{2+}\right)$ berpengaruh terhadap aktivitas enzim $\alpha$ amilase dan glukoamilase. Pada grafik 2 dan 3 menunjukkan bahwa dengan penambahan ion $\mathrm{Ca}^{2+}$ dan $\mathrm{Mg}^{2+}$ (ion divalent) aktivitas enzim $\alpha$ amilase dan glukoamilase yang lebih baikk, dimana aktivitas enzim $\alpha$-amilase dan glukoamilase mengalami kenaikan karena kedua ion ini dapat mengganti ion logam tidak efektif yang terikat pada sisi-aktif enzim $\alpha$ amilase dan glukoamilase dan membuat enzim kedua ion logam ini merupakan aktivator yang baik dibandingkan dengan ion $\mathrm{Na}^{+}$dan $\mathrm{K}^{+}$.

Tabel 3. Aktivitas Enzim Glukoamilase

\begin{tabular}{|c|c|c|c|c|}
\hline \multirow{2}{*}{$\begin{array}{c}\text { Konsentrasi } \\
(\%)\end{array}$} & \multicolumn{4}{|c|}{ Aktivitas enzim glukoamilase setelah penambahan } \\
(Unit/mL)
\end{tabular}




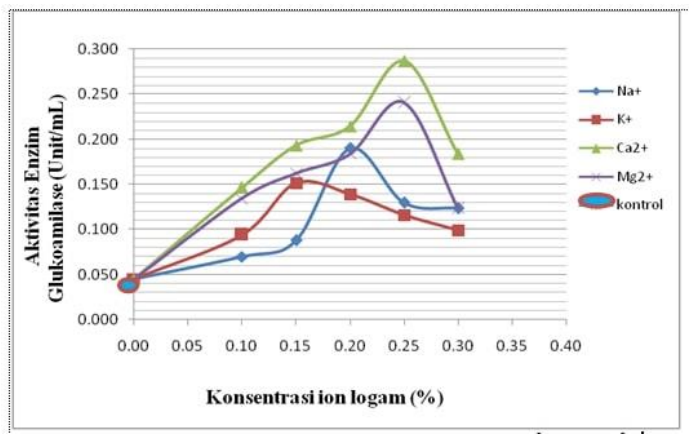

Gambar 3. Aktivitas Enzim Glukoamilase

Dari keseluruhan penambahan ion logam yang paling optimum dari keseluruhan perlakuan yang diberikan adalah ion $\mathrm{Ca}^{2+}$ dengan konsentrasi $0,25 \%$.

\section{Kadar Protein Senyawa Prebiotik}

Adapun kadar protein yang diperoleh dengan penambahan ion logam logam $\mathrm{Na}^{+}, \mathrm{K}^{+}$, $\mathrm{Mg}^{+}$dan $\mathrm{Ca}^{2+}$ dan kadar protein tanpa penambahan ion logam selama proses fermentasi sebagai berikut.

Tabel 4. Kadar Protein

\begin{tabular}{|c|c|c|c|c|}
\hline \multirow{2}{*}{$\begin{array}{c}\text { Konsentrasi } \\
(\%)\end{array}$} & \multicolumn{3}{|c|}{ Kadar Protein $(\mathrm{mg} / \mathrm{mL})$ setelah penambahan } \\
\cline { 2 - 5 } & \multicolumn{1}{|c|}{ Kontrol $=1,196$} \\
\cline { 2 - 5 } $\mathrm{Na}^{+}$ & $\mathrm{K}^{+}$ & $\mathrm{Ca}^{2+}$ & $\mathrm{Mg}^{2+}$ \\
\hline 0.10 & 1.346 & 1.442 & 2.167 & 1.667 \\
\hline 0.15 & 1.453 & 1.860 & 2.196 & 1.814 \\
\hline 0.20 & 1.842 & 1.774 & 2.285 & 1.871 \\
\hline 0.25 & 1.606 & 1.689 & 2.724 & 2.381 \\
\hline 0.30 & 1.660 & 1.531 & 2.117 & 1.592 \\
\hline
\end{tabular}

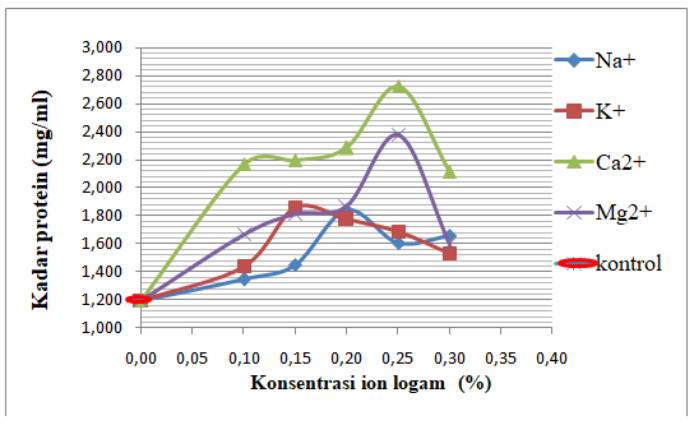

Gambar 4. Kadar protein

Pada tabel 4 dan grafik 4 memperlihatkan bahwa dengan penambahan ion logam pada konsentrasi yang berbeda berpengaruh terhadap kadar protein senyawa prebiotik. Ion $\mathrm{Na}^{+}$dicapai pada konsentrasi optimum $0,20 \%$ dengan kadar protein $1,842 \mathrm{mg} / \mathrm{mL}$, ion $\mathrm{K}^{+}$ dicapai pada konsentrasi optimum 0,15\% dengan kadar protein sebesar 1,860 mg/mL, ion $\mathrm{Ca}^{2+}$ dan ion $\mathrm{Mg}^{2+}$ dicapai pada konsentrasi optimum $0,25 \%$ dimana kadar protein yang diperoleh masing-masing sebesar 2,724 mg/mL dan 2,381 mg/mL. Dari keseluhan penambahan ion logam, kadar protein yang optimum dicapai pada penambahan ion $\mathrm{Ca}^{2+}$ pada konsentrasi $0,25 \%$.

\section{Kadar Biomassa Sel}

Biomassa yang dihitung adalah berat sel yang dihasilkan oleh ragi Endomycopsis fibuligera setelah enzimnya terlepas dari membranj sel. Produk hasil fermentasi diambil sebanyak $5 \mathrm{~mL}$ lalu disaring kemudian dikeringkan, berat sel yang diperoleh dianggap sudah tidak mengandung enzim lagi.

Adapun hasil yang diperoleh adalah sebagai berikut.

Tabel 5. Bimassa Sel

\begin{tabular}{|c|c|c|c|c|}
\hline \multirow{2}{*}{$\begin{array}{c}\text { Konsentrasi } \\
(\%)\end{array}$} & \multicolumn{4}{|c|}{ Biomassa sel setelah penambahan $(\mathrm{mg} / \mathrm{mL})$} \\
\cline { 2 - 5 } & \multicolumn{1}{|c|}{ Kontrol $=4,3533$} & \multicolumn{2}{|c|}{} \\
\cline { 2 - 5 } & $\mathrm{Na}^{+}$ & $\mathrm{K}^{+}$ & $\mathrm{Ca}^{2+}$ & $\mathrm{Mg}^{2+}$ \\
\hline 0.1 & 5.1367 & 4.9533 & 5.8567 & 5.9567 \\
\hline 0.15 & 6.4967 & 7.4133 & 8.4500 & 7.0500 \\
\hline 0.2 & 8.1367 & 6.3800 & 9.7900 & 8.4133 \\
\hline 0.25 & 7.3533 & 5.8067 & 10.8933 & 9.3633 \\
\hline 0.3 & 5.1100 & 4.3867 & 7.1367 & 6.5767 \\
\hline
\end{tabular}

Dari tabel 5 dan grafik 5 menunjukkan bahwa di atas memperlihatkan bahwa penambahan ion logam monovalen dan divalen berpengaruh terhadap biomassa sel dibandingkan biomassa sel yang dihasilkan tanpa penambahan ion logam (sebagai kontrol). Penambahan ion $\mathrm{Na}^{+}$diperoleh pada konsentrasi optimum 0,20\% sebesar 8,1367 $\mathrm{mg} / \mathrm{mL}$, ion $\mathrm{K}^{+}$diperoleh pada konsentrasi optimum $0,15 \%$ sebesar $7,4133 \mathrm{mg} / \mathrm{mL}$, ion $\mathrm{Ca}^{2+}$ dan $\mathrm{Mg}^{2+}$ dicapai pada konsentrasi 0,25\% masing-masing sebesar 10,8933 dan 9,3633 $\mathrm{mg} / \mathrm{mL}$. Dari keseluhan penambahan ion logam, kadar biomassa sel yang optimum dicapai pada penambahan ion $\mathrm{Ca}^{2+}$ pada konsentrasi $0,25 \%$.

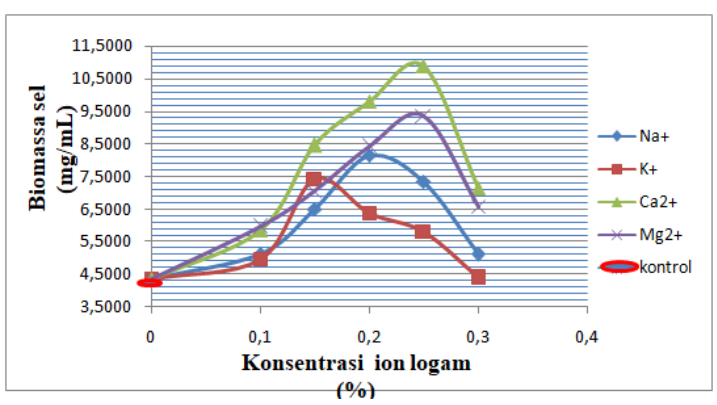

Grafik 5. Biomassa Sel 
Jika dihubungkan dengan terhadap perubahan aktivitas enzim sebagimana yang diuraikan di atas maka dapat dikatakan bahwa penambahan ion logam $\mathrm{Na}^{+}, \mathrm{K}^{+}, \mathrm{Mg}^{2+}$ dan $\mathrm{Ca}^{2+}$ berpengaruh terhadap reproduksi produksi sel oleh ragi Endomycopsis fibuligera tetapi tergantung jenis ion logam, konsentrasi dan perbandingan yang sesuai.

Analisis menggunakan spektrofotometer UV-VIS menunjukkan bahwa penambahan logam pada prebiotik mempengaruhi peningkatan kadar protein, glukoamilase, alfa amilase, gula pereduksi, dan biomassa sel dan peningkatan yang yang paling tinggi pada logam $\mathrm{Ca}^{+}$dengan konsentrasi $0,25 \%$.

Pengujian Senyawa Prebiotik dengan Jenis dan Konsentrasi Ion Logam yang Optimum (Ion $\mathrm{Ca}^{2+}$ dengan Konsentrasi 0,25\%) pada Ternak Ayam Pedaging

Mikroba tau bakteri pada umunya pasti akan dihubungkan dengan masalah penyakit yang mengganggu kesehatan ternak ayam, misalnya bakteri Escheria aureus, Bacillus cereus, Colostridum perferingens, Colostridum botulinum, Streptococcus faecalis dan sebagainya (dikenal sebagai bakteri patogen atau jahat). Di samping itu ternyata dikenal pula bakteri yang bermanffat bagi kesehatan ternak ayam (bakteri baik) yaitu bakteri yang secara alami berada di dalam tubuh ternak.

Tabel 6. Data Rata-rata Berat Badan Ayam Pedaging dengan Pemberian Senyawa Prebiotik

\begin{tabular}{ccc}
\hline & \multicolumn{2}{c}{ Perlakuan } \\
\cline { 2 - 3 } Hari & $\begin{array}{c}\text { Dengan } \\
\text { Penambahan } \\
\text { ion logam } \\
\text { (g) }\end{array}$ & $\begin{array}{c}\text { Tanpa } \\
\text { Penambahan } \\
\text { ion logam } \\
\text { (g) }\end{array}$ \\
\hline 0 & 46 & 40 \\
\hline 5 & 99 & 87 \\
\hline 10 & 212 & 183 \\
\hline 15 & 404 & 353 \\
\hline 20 & 674 & 605 \\
\hline 25 & 1056 & 977 \\
\hline 30 & 1744 & 1483 \\
\hline
\end{tabular}

Dari uji statistik yang dilakukan menunjukkan perbedaan signifikan dimana berat ayam pedaging yang diberi prebiotik dengan penambahan ion logam penimbangannya lebih berat bila dibandingkan berat badan ayam potong yang diberi prebiotik tanpa penambahan ion logam. Berdasarkan pada tabel 6 dan gambar 6, dari kedua senyawa prebiotik yang diberi pada ternak ayam, terjadi perbedaan berat badan yang cukup jauh antara ayam yang diberi senyawa prebiotik tanpa penambahan ion logam yaitu selisih berat ratarata 261 gram atau sekitar $15 \%$ pada hari ke-30. Hal tersebut disebabkan karena semakin tinggi kadar senyawa prebiotik yang dihasilkan menyebabkan tubuh ayam pedaging menjadi lebih sehat dan memiliki bobot lebih dibandingkan dengan ayam pedaging yang biasanya diproduksi oleh peternak pada umumnya.

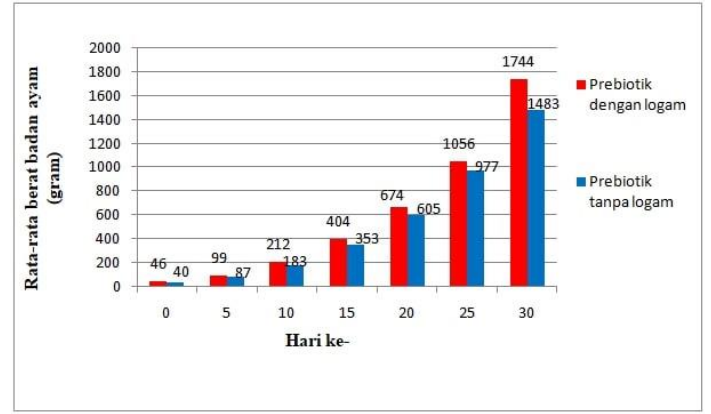

Gambar 6. Pengaruh Pemberian Senyawa

\section{Kesimpulan}

Berdasarkan hasil penelitian yang dilakukan dapat disimpulkan bahwa dari semua perlakuan yang diberikan kondisi terbaik diperoleh pada penambahan ion logam $\mathrm{Ca}^{2+}$ pada konsentrasi 0,25\% dimana kadar gula pereduksi $0,600 \mathrm{mg} / \mathrm{mL}$, aktivitas enzim $\alpha-$ amilase dan glukoamilase masing-masing 0,519 dan 0,287 unit $/ \mathrm{mL}$, kadar protein $2,724 \mathrm{mg} / \mathrm{mL}$, biomassa sel 10,8933 mg/mL. Melalui pengamatan pemberian senyawa prebiotik dengan penambahan ion logam dan pemberian senyawa prebiotik tanpa penambahan ion logam berpengaruh terhadap pertambahan berat badan ayam pedaging dengan selisih berat rata-rata 261 gram atau $15 \%$ pada hari ke30. Dari hasil penelitian ini juga dapat disimpulkan bahwa prebiotik dapat mengurangi penggunaan antibiotik. 


\section{DaftarPustaka}

1. Hernot, D. C.; Boileau, T. W.; Bauer, L. L.; Middelbos, I. S.; Murphy, M. R.; Swanson, K. S.; Fahey Jr, G. C., In vitro fermentation profiles, gas production rates, and microbiota modulation as affected by certain fructans, galactooligosaccharides, and polydextrose. Journal of Agricultural and Food Chemistry 2009, 57, (4), 1354-1361.

2. Lomax, A. R.; Calder, P. C., Prebiotics, immune function, infection and inflammation: a review of the evidence. British Journal of nutrition 2008, 101, (5), 633-658.

3. Biggs, P.; Parsons, C. M., The effects of several organic acids on growth performance, nutrient digestibilities, and cecal microbial populations in young chicks. Poultry science 2008, 87, (12), 25812589.

4. Kartini. Pemanfaatan Tepung Sagu Untuk Produksi Senyawa Prebiotik Pada Ternak DOC ( Daily Old Chicken). Politeknik Negeri Ujung Pandang, Makassar, 2004. 